\title{
The Role of Government in Overcoming Industrial Development Impact towards Environmental Sustainability
}

\author{
Bayu Mitra Adhyatma Kusuma ${ }^{1,2}$ \\ ${ }^{1}$ Department of Public Administration, Faculty of Administrative Science, University of Brawijaya, Malang, East Java, \\ Indonesia \\ ${ }^{2}$ Department of Political Science in Security Resources Management, Faculty of Political Science and Law, Burapha \\ University, Chonburi, Thailand
}

\begin{abstract}
Indonesia is actively implementing of national development. In order to realize the national development, the government has tried to do various efforts. One of them is pushing the pace of the national economy. The industrial sector is the mainstay of the government to boost the economy in Indonesia. Developments in the industry cannot be separated from the utilization of natural resources; both renewable resources and non-renewable resources. But on the other hand, the industrial development has a negative impact on the creatures and the environment. Development in the industrial sector has led to a variety of effects such as increased pollution resulting from industrial production processes to ecological disaster. The facts of environmental damage that occurred in Indonesia today should be seen as a whole and comprehensive for immediate rescue efforts. As we know, in Indonesia has implemented Government Regulation No. 27 Year 1999 on Environmental Impact Assessment (EIA). However, the environmental pollution caused by the industrial sector development is still happening today. The results of research show that there are three basic principles that made by the government to control the environmental damage caused by the industrial development, namely administratively, technologically, and instructively. Industrial development is a process that moves in a straight line, from the backward communities to advance society. But promoting the advancement of society should not be paid for environmental damage. It should be the role of government and public awareness to run environmentally sound technology and environmentally sound development to solve these issues. In this research the author used qualitative research type, descriptive approach and emphasis in literature study.
\end{abstract}

Keywords: Role of Government, Industrial Development, Environmental Sustainability

\section{INTRODUCTION}

Currently, Indonesia is actively implementing of national development. The national development effort is a series of sustainable development which includes the entire life of the community, nation, and state to achieve national goals as mandated in the Preamble of the Constitution of 1945. In order to realize the lofty ideals of Indonesia, the government has tried to do various efforts in order to push the pace of national development. One such effort is the economic development, as we know that the development in this sector is the main capital to alleviate poverty.

As stated by Siagian (2009) that it seems there is no other alternative for humanity except keep trying to improve cooperation within the framework of economic activities in the field because the only way that poverty can be alleviated, the gap between people in rich countries with people in other parts of the world

\footnotetext{
${ }^{1}$ Coressponding Address:

Bayu Mitra Adhyatma Kusuma

Email : bayumitraa.kusuma@yahoo.com

Address : Jl. Kutilang No. 1, Krajan 1/I, Sembulung, Cluring, Banyuwangi, 68482
}

can be minimized and the economic gap contained within a country between the haves and the have not can be eliminated or at least minimized.

Encouraging the industrial growth rate of is the mainstay of the government in an effort to boost the economy in Indonesia. Over the last twenty years, Indonesia's economic development towards industrialization. Not less than 30,000 industrial companies operating in Indonesia from year to year showed an increase (Walhi, 2010). Although Indonesia basically is an agricultural country, Indonesian economy will be more developed quickly with the support of industrial sector as the dominant partners in the economic development (www.walhi.org.id).

But on the other hand, the development of industry led to negative impacts on the creatures and the environment. Development in the industrial sector has led to a variety of effects such as increased pollution resulting from industrial production processes and ecological disaster. As stated by Wagner (1971) that the many inorganic substances negatively that interact with psychological system, mercury, lead, beryllium, and asbestos are potentially the 
most dangerous because of they are stored in the body and have a cumulative effect. While Mayer (2001) said that even before the industrial revolution, society had to deal with hazardous waste materials and today the problem is much larger as industrialized societies use sophisticated materials and chemicals pose serious risks that often to humans, wildlife, and the environment.

Basically, the government has issued several policies that can be used as an umbrella law for government officials and communities to act to preserve the environment like Law Number 4 Year 1982 about Basic Provisions of Environmental Management and Government Regulation No. 27 Year 1999 about Environmental Impact Assessment (EIA). But in fact, the environmental pollution caused by the industrial sector is still happening today. Indonesia's environmental sustainability threatened with collapse.

Achieving environmental sustainability is one of the points in the Millennium Development Goals (MDGs) that have been declared by the United Nation. Environmental sustainability requires the design and provision of products and services that incorporate and promote waste minimization and the efficient and effective use and reuse of resources (Industry Skills Council, 2009). Understanding and use of the word environmental often tends to be associated with some kind of human impact on natural systems. According Morelli (2013), more specifically, environmental sustainability could be defined as a condition of balance, resilience, and interconnectedness that allows human society to satisfy its needs while neither exceeding the capacity of its supporting ecosystems to continue to regenerate the services necessary to meet those needs nor by our actions diminishing biological diversity

European Commission (2006) stated that industrial processes play a major role in the degradation of the global environment. In industrialized countries, environmental regulation and new technologies are reducing the environmental impact per unit produced, but industrial activities and growing demand are still putting pressures on the environment and the natural resource base. Still according European Commission (2006), in the developing countries a double environmental effect is occurring: old environmental problems, such as deforestation and soil degradation, remain largely unsolved. Nature is no longer able to function to provide its services, the crisis became daily diet should be borne by the common people, disasters are happening everywhere. In 2009, a total of 1,713 total disaster happened in Indonesia (Walhi, 2010). The facts of environmental damage in Indonesia which occurred on this day should be read comprehensively for immediate efforts to overcome. Incomprehension on the environmental changes that occur may be the price paid by residents of the development history.

Industrial development is essentially aimed at the nation's prosperity. Industrial development may reduce the dependence on the agricultural sector. This is because the Indonesian society in general livelihood of farmers with a high dependence on the agricultural sector. But it turns out the construction industry impact on the environment that can inhibit human survival. Thus efforts to maintain the environment that can support life should be done with full awareness. Like statement by Todaro and Smith (2003) that the demand to fulfill consumption alive need then increase while watch over so that permanent environment degradation stay in minimal standard genuinely be task bot at all can be said little. Based on the above description, this study describes role of government in overcoming industrial development impact towards environmental sustainability.

\section{RESEARCH METHOD}

This research use qualitative type of research, descriptive approach, and emphasize to literature study. Its richness and complexity mean that there are different ways of analyzing social life, and therefore multiple perspective and practices in the analysis of qualitative data (Punch, 2004).

\section{Data Collecting Technique}

Data collecting method are the main objective of the research to get the data, so that data collecting method is the strategic step in this research. The data collection techniques used in this research is:

\section{Observation}

Observation has a long tradition in social science (Punch, 2004). Observation is data collection by the object that is researching on the circumstances and the reality to recheck the information collected from the secondary data. The observation is to support the researcher to solve the problem and provide additional data that support the result. Direct observation conducted at the site of Sidoarjo hot mudflow 
disaster caused by PT. Lapindo Brantas exploration and gold mining site in the Banyuwangi Regency with the help of NGO Wahana Lingkungan Hidup (Walhi).

Related Text and Document

Text and document are not only produced, but also, in turn, productive (Prior, 2010). Document both historical and contemporary are rich source of data for social research. It is mean to obtain or to get accurate theories and references regarding data of the result findings by studying relevant rules, regulations, reports, documents and literatures.

Data Analysis Technique

Researcher use qualitative data analysis model of Miles and Huberman. Data analysis techniques of Miles and Huberman (1994) consist from four activities:

Data Collection

Data collection is an activity when researchers collect data needed for the study through the steps in the data collecting process.

\section{Data Reduction}

Data reduction refers to process of selecting, focusing, simplifying, abstracting, and transforming the data that appears in written up field notes or transcription.

\section{Data Display}

Data display is an organized, compressed assembly of data and information that permits conclusion drawing and action Data display can be done in the form of a short description, charts and or relationships category.

\section{Conclusion}

Conclusion is an activity to conclude the records of the court where the initial conclusions presented are temporary and will be changed if they do not find strong evidence to support the next phase of data collection. The meanings of data have to be tested for their validity.

\section{RESULT AND DISCUSSION Result}

With the demise of the cold war, new concept of security that addressed not only the military realities of the contemporary world but also the political, economic, and social realities were developed (Snyder, 2008). And then United Nations Development program or UNDP (1994) proposed that human security concept consist from economic security, food security, health security, environmental security, personal security, community security, and political security. As one element of security that is needed by humans is environmental security. But the environmental conditions at this time threatened by industrial development.

Industrial development is a positive effort, but in addition the construction industry has also led to a negative impact on the environment. Irresponsible industrial development can lead to several things such as the lack of clean air that is absolutely required by all living things. Due to the shrinking of tropical forests, increasing the level of pollution that is getting out of control, water pollution, land degradation, and increasing the concentration of hazardous chemicals from industrial waste can be used as an indication of the environmental damage caused by industrial development.

A concrete example of irresponsible industrial development is such a hot mudflow tragedy in Sidoarjo Regency, East Java caused by PT. Lapindo Brantas, the pollution caused by industrial waste in Buyat gulf, North Sulawesi by PT. Newmont Minahasa, the destruction of forests in Papua caused by PT. Freeport Indonesia, gold mining in the Banyuwangi Regency which is a protected forest areas and many more. The maintaining failure of the production operational standards in industrial development causing environmental damage and endanger people's lives around. Another impact of the construction industry towards environmental sustainability, among others, is the occurrence of floods, droughts, soil erosion, pollution of the environment, the death of several species of plants and animals. Industrial development is closely related to changes in land use. Change of use of land for industrial development will have a major impact for the region itself and the surrounding area.

If the bureaucracy or the government can implement their function properly, then keep the environment from the harmful effects of industrial development will be carried out easily as well. The trick is to apply the proper and clear zoning between industrial areas and conservation areas or other environments. The government must be firm and consistent in applying them so that industrial development and environmental sustainability is maintained. Participation or input from the community should be considered as something positive because there are no checks and balances when one party in a conflict with the interests of other parties.

Planning and decision making by state agencies relating to issues of industrial development and the environment requires a 
comprehensive understanding, especially by actors on issues related to policy makers. This departs from the understanding of academic knowledge and strengthened by the data field that can produce scale-based populist policies in general and ecology in particular. Policies that can be done to maintain the environmental sustainability of industrial development is a threat to environmentally sound development policies, especially with respect to efforts to use natural resources while maintaining aspects of the maintenance and preservation of the environment.

It can be said that the development in the industrial sector plays a very important role in the economic development in Indonesia, so the government is really encouraging this progress. According Ministry of Industry (2013), value of investments in non-oil manufacturing industries in Indonesia alone is projected to reach IDR 223.64 trillion in 2013. This figure is much higher than predicted achievement by the end of this year to IDR 160 trillion. That's if we assuming domestic investment trends and foreign direct investment (FDI) during January-September 2012 is still continuing (www.kemenperin.go.id)

Various policies have been implemented by the government in its efforts to push the pace of industrial development in Indonesia. Regulation is made in such a way to facilitate the investors who will invest in Indonesia. It is expected to push the pace of industrial development in Indonesia. But besides that, there are also other important things must be considered and carried out by the government, namely to prevent and cope the impact of industrial development, in particular the impact on the environmental sustainability.

Generally the government through the Ministry of the Environment of the Republic of Indonesia (2012) has had a clear role in keeping environmental sustainability through a variety of programs, among others (www.menlh.go.id):

1. Water pollution control program: Handling of domestic waste, industrial waste management, handling of solid waste/garbage, and control of agricultural wastes;

2. Environmental damage control program: Control of critical land, control of water catchment areas, rehabilitation of flood plains;

3. Spatial Program: Revised layout, monitoring and evaluation;

4. Law enforcement programs: Warning letter (administrative penalties), revocation of business/environmental, and law enforcement (civil and criminal penalties);

5. Community empowerment program: Increased public awareness and community economic development.

And when we look more specifically, there are three basic principles that can be done in order to control the environmental damage caused by industrial development, which is administratively, technologically, and is instructively.

In administratively, the government programs include environmental damage control program, spatial program and law enforcement program. The government can issued environmental quality standards. Environmental quality standards are an indicator to determine the quality of the environment. Besides, the government also issued a program that covers a variety of sectors within sustainable development which is expected to take place sustainable development by maintaining the function of a sustainable environment. The existence of this regulation must also be supported by strong law enforcement. Because as much as any rules, without a strong law enforcement then all will be in vain. In addition, the government must play an important role in the conservation management activity for environmental sustainability. Stavins (2000) states that among the most difficult, hazardous waste problems posed by the waste generated in quantities small enough to be stored, shipped, and the dumper is more or less anywhere in the environment.

Rules to control industrial development are Environmental Impact Assessment (EIA) or in Indonesian language call AMDAL. The scope and coverage of EIA include:

1. Reporting systems as a means of monitoring the performance of activities;

2. Monitoring by companies, governments, public, and media as an evaluation tool to stakeholders and corporate performance accountability reports to the public.

This requirement contains a number of standards that can be scientifically tested and its implementation should be monitored regularly. EIA should not be seen merely as the cost and complexity of the bureaucracy, but also an asset because of the arrangement and good environmental management will be able to ensure continuity of operations of the company for the long term. Meanwhile, if there are 
significant violations, in addition to a business license can be revoked; the offender can be charged with destruction of the environment in accordance with Government Regulation No. 27 Year 1999 Article 35 which may be subject to liability to pay compensation directly and immediately after the occurrence of pollution and/or destruction of the environment.

In technologically, the government programs include water pollution control program and environmental damage control program. The way is to build a wastewater treatment facility that is managed by the government. In addition to the wastewater treatment facility owned by their respective companies, governments also provide these facilities; at least the government has a role in the research and development. Example of a waste treatment facility is the wastewater treatment plant treating wastewater prior to discharge to the environment. Every industry must have industrial waste management technologies that are safe, so that the waste generated by the industry is not harmful for environmental sustainability.

In addition it would be nice if the government implements Environmentally Sound Technology. Environmentally Sound Technologies (ESTs) are technologies that have the potential for significantly improved environmental performance relative to other technologies. ESTs protect the environment, are less polluting, use resources in a sustainable manner, recycle more of their wastes and products, and handle all residual wastes in a more environmentally acceptable way than the technologies for which they are substitutes (UNEP, 2003). The development and application of environmentally friendly technologies have great potential to achieve the two goals of environmental sustainability and economic growth.

And in instructively, the government program include community empowerment program through increased public awareness and develop economy of community. The government can instruct the application of environmentally sound development. In the environmentally sound development, the government in this case is represented by the Ministry of Environment, Environment Agency (BLH) and other related agencies should be able to anticipate as early as possible the possibility of environmental contamination. Government should be instructed on the use of environmentally clean technology because of concern for the environment not only for society but also for the sheer industrial

\section{company itself.}

\section{Discussion}

Based on the above explain, the author argues that resistance to save the environment from the impacts of industrial development is the presence of environmentally sound technology and environmentally sound development. Environmentally sound technologies (ESTs) are not just individual technologies. ESTs can also be defined as total systems that include know how, procedures, goods and services, and equipment, as well as organizational and managerial procedures for promoting environmental sustainability.

According UNEP (2003), technologies reflect our cultural values and historically have altered the nature of human consciousness. Technologies, by their very presence, often force us into searching for solutions to problems that become defined as technological, even though many of these problems may not have been technological to begin with. And appropriate ways for the development is environmentally sound development which optimizes the benefits of natural resources and human resources by way of conditioning the human ability to preserve the environment. There are two important aspects of major concern, which is the environment and development. From these two things means that development is good development of environmentally sound development standpoint.

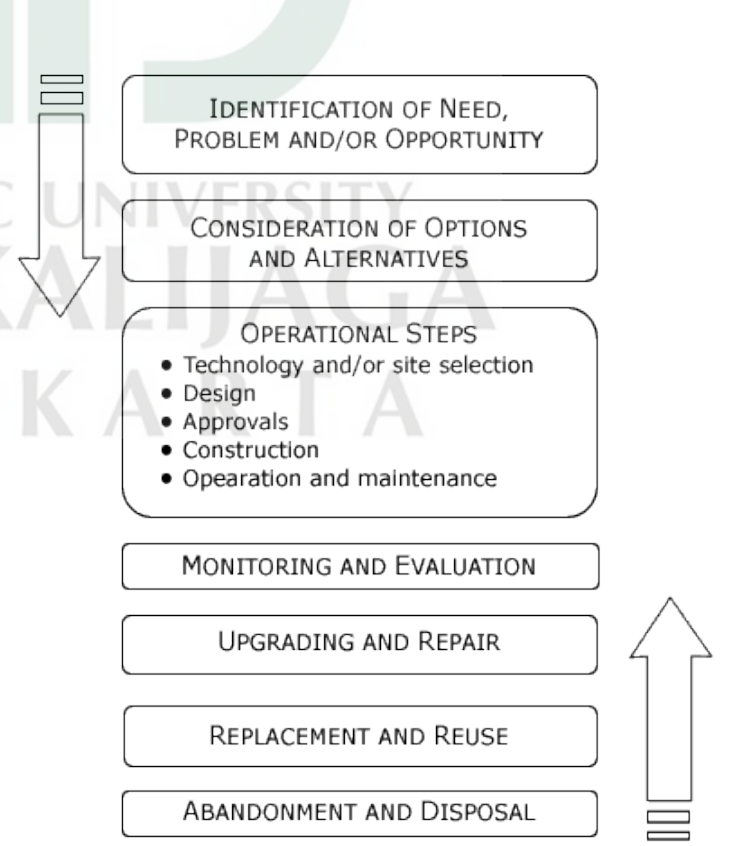

Figure 1. Technology Development Cycle (Source: United Nation Development Program, 2003) 
Technology and development are very closely linked. The use of environmentally friendly technologies in the industrial development process can preserve the environment. This requires a good understanding of the intersecting elements of development, the alternative, environmentally sound development strategies and related technologies. Figure below shows the relation between technology and development, including can be implementing in the industrial development.

From the figure above we can better understand the close relationship between technology and the development of mutual influence in maintaining environmental sustainability. In the concept of environmentally sound development and sustainable aspects should be consistent and fully integrated and taken into account in determining the absolute development policy, in this case the construction industry. With the construction of this model is expected to create sustainability that can be worn continuously until the time is not unlimited. Suppose is a simple example, if all the wood that now we spend this year, the next generation will not know the name of timber.

This is a simple illustration example of environmentally sound development. How do us as generations are now able to ensure the availability of clean air, abundant water, green forests, diverse flora and fauna, the sea is not polluted and rich seafood for the next generation.

Environmentally sound development is the effort to improve the human quality is gradually taking into account environmental factors. Based on the above description, in summary the characteristics of environmentally sound development, among others:

1. Done with careful planning by knowing and understanding the strengths, weaknesses, opportunities, and threats that are owned and which may arise later on;

2. Attention to the environmental carrying capacity so as to support the sustainability of development;

3. Minimize the impact of pollution and environmental damage; and

4. Involve the participation of citizens, especially the people residing in the vicinity of industrial development.

In the construction of environmentally sound development oriented, one of the most important things is the environmental sustainability can be assured. In order to environmentally sound development work properly, then the government and its practitioners in the industrial development need to have foresight is defined as the development of vision and can be implemented into an ideal long-term development and oriented to the interests of all people. Vision development in question is the achievement of improved quality of life for all people through the development of human resources that respond to industry developments, as well as how to manage natural resources wisely and sustainably.

\section{CONCLUSION}

Indonesia is actively implementing of national development, especially industrial development. Industrial development is a positive effort, but in addition the construction industry has also led to a negative impact on the environment. Irresponsible industrial development can lead to environmental damage. Indonesia has implemented Government Regulation No. 27 Year 1999 on Environmental Impact Assessment (EIA). However, the environmental pollution caused by the industrial sector is still happening today. In order to overcoming industrial development impact towards environmental sustainability, there are three basic principles that made by the government, namely administratively, technologically, and instructively. And as a recommendation to strengthen government efforts to overcoming the industrial development impact towards environmental sustainability, the government can set environmentally sound technology and environmentally sound development as a standard reference in industrial development. Industrial development is a process that moves in a straight line, from the backward communities to advance society. But promoting the advancement of society should not be paid for environmental damage. So that why the authors concluded that is very important to strike a balance between industrial development and environmental sustainability.

\section{ACKNOWLEDGEMENT}

The author would like to thank the Head of the Master Program of Public Administration, Faculty of Administrative Science, University of Brawijaya, Drs. Andy Fefta Wijaya, MDA, Ph.D and Dr. Boonruam Napachoti, Ph.D from Faculty of Political Science and Law, Burapha University, Thailand for any input, guidance and direction 
both as a lecturer or supervisor for the author during the double degree master's program.

\section{REFERENCES}

European Commission. (2006). Environment Fact Sheet: Industrial Development. Office for Official Luxembourg: Publications Office of the European Communities.

Government of the Republic of Indonesia. (1982). Law of the Republic of Indonesia No. 4 Year 1982 about Basic Provisions of Environmental Management. Jakarta: Government of the Republic of Indonesia.

Government of the Republic of Indonesia. (1999). Government Regulation No. 27 of 1999 about Environmental Impact Assessment. Jakarta: Government of the Republic of Indonesia.

Industry Skills Council. (2009) Environmental Sustainability: An Industry Response. Sydney: Industry Skills Council.

Mayer, R. (2001). Connection in Environmental Science. New York, USA: McGraw-Hill Companies.

Miles, MB. and Hubberman AM. (1994). Qualitative Data Analysis: A Sourcebook of a New Method. London: Sage Publication.

Ministry of Environment of the Republic of Indonesia. 2012. Banjir-Longsor dan Solusi Penanganannya. Retrieved on April 4, 2014 from www.menlh.go.id.

Ministry of Industry of the Republic of Indonesia. (2013). 2013, Investasi Manufaktur Rp 223 T. Retrieved on April 4, 2014 from www.kemenperin.go.id.

Morelli, J. (2013). Environmental Sustainability: A Definition for Environmental Professionals. Journal of Environmental Sustainability Vol. 1, Issue. 1, 2013.

Prior, L. (2010). Using Documents in Social Research. In Silverman, David. Qualitative Research. 3rd ed. London: Sage Publication.

Punch, KF. (2004). Introduction to Social Research: Qualitative and Quantitative Approach. 2nd ed. London: Sage Publication.

Siagian, SP. (2007). Administrasi Pembangunan: Konsep, Dimensi, dan Strateginya. Jakarta: Bumi Aksara.

Snyder, CA. (2008). Contemporary Security and Strategy. 2nd ed. New York: Palgrave Macmillan.

Stavins, RN. (2000). Environmental Economic and Public Policy. Cheltenham: Edward Elgar.
Todaro, MP. and Smith, SC. (2003). Economy Development at the Third World. Jakarta: Erlangga.

United Nation Environmental Program (UNEP). 2003. Phytotechnologies: A Technical Approach in Environmental Management. Tokyo: United Nation Environmental Program

United Nations Development Program (UNDP). (1994). Human Development Report 1994. Oxford: Oxford University Press.

Wagner, R. (1971). Environment and Man. New York: WW. Norton.

Wahana Lingkungan Hidup (Walhi). (2010). Industrialisasi dan Lingkungan. Retrieved on March 25, 2014 from www.walhi.org.id. 